UDC 78.02+781.4+787.6/.7
DOI https://doi.org/10.31723/2524-0447-2019-29-2-21

\author{
Irina Vladimirovna Formanyuk \\ ORCID: 0000-0002-2523-2858 \\ Senior Lecturer at the Department of Folk Instruments \\ Odessa National A. V. Nezhdanova Academy of Music

\section{FEATURES OF THE SPATIAL AND TEXTURAL ORGANIZATION OF COMPOSITIONS FOR DOMRA WITHOUT ACCOMPANYING}

\begin{abstract}
Aim of the work. The article explores the principles and methods of texture formation in music for solo instruments (unaccompanied) in the historical, structural and functional, instrumental and specific aspects. The research methodology includes the use of aesthetic and cultural, historical, structural and functional musicological methods, which form a single methodological basis. The scientific novelty of the article is expressed in the identification of the formative, intonational and melodic, spatially-shaped functions of the texture in the compositions for the solo instrument. The specificity of the domra instrumental texture in the indicated functions is revealed. Conclusions. In the music of the XX century, the actualization of solo instrumental forms for strings and wind instruments, traditionally accompanied by a piano, ensemble or orchestra is observed. Over the centuries of its existence, this genre has developed its own textural forms of a mixed type. Their naturallinear development principle gradually absorbed various types of polyphonic musical texture (hidden and explicit polyphony, homophonic and harmonic elements, sonoristics), which is based on the immanent intonation properties of the complicated melody, and also created its own specific ones. The mentioned above requires special performing hearing and methods of embossing in a holistic linear-vertical-deep spatial development of solo instrumental texture.

The specifics of domra instrumentalism (the location of all strings in one plane, the possibility to simultaneously use different methods of sound extraction, specific instrumental methods) provides significant opportunities for differentiated performance and combinatorics of homophonic and polyphonic textural formations. This allows to deploy complex drama in various genre and style forms of solo domra instrumentalism.
\end{abstract}

Key words: solo for string musical instruments, texture, hidden polyphony, homophony, polyphony, domra.

Форманюк Ірина Володимирівна, старший викладач кафедри народних інструментів Одеської національної музичної академії імені А.В. Нежданової 
Особливості просторово-фактурної організації творів для струнних інструментів без супроводу

Мета роботи. У статті досліджуються принципи і способи фактуроутворення в музиці для інструментів соло (без супроводу) в історичному, структурно-функиіональному $i$ інструментально-специфічному аспектах. Методологія дослідження включає використання естетико-культурологічного, історичного, структурно-функціонального музикознавчих методів, які утворюють єдину методологічну основу. Наукова новизна статті виражсається у виявленні формотворчої, інтонаційно-мелодійної, просторово-образної функцій фактури в творах для інструменту-соло. Виявляється спещифіка домрової інструментальної фактури в зазначених функціях. Висновки. У музиці ХХ століття спостерігається актуалізація сольних інструментальних форм для струнних та духових інструментів, традиційно звучать у супроводі фортепіано, ансамблю або оркестру. За кілька століть свого існування цей жанр виробив власні фактурні форми змішаного типу. Ïх природно-лінеарний принцип розвитку поступово вбирав різні види багатоголосої музичної тканини (приховане і явне багатоголосся, гомофонно-гармонійні елементи, сонористика), що грунтується на іманентних інтонаційних властивості ускладнюеться мелодики, а також створював власні, специфічні. Перераховане вимагає спеціального виконавського слухання i способів рельєфного виділення в умовах цілісного лінеарно-вертикально-глибинного просторового розвитку сольної інструментальної тканини.

Специфіка домрового інструменталізму (розташування всіх струн в одній площині, можллвість одночасного використання різних прийомів звуковидобування, специфічні інструментальні прийоми) надає значних можливостей диференційованого виконання і комбінаторики гомофонно-поліфонічних фактурних утворень. Це дозволяє розгортати складну драматургію в різних жсанрово-стильових формах сольного домрового інструменталізму.

Ключові слова: соло для струнних музичних інструментів, фактура, багатоголосся, приховане багатоголосся, гомофонія, поліфонія, домра.

Форманюк Ирина Владимировна, старший преподаватель кафедры народных инструментов Одесской национальной музыкальной академии имени А. В. Неждановой

Особенности пространственно-фактурной организащии произведений для струнных инструментов без сопровождения

Цель работы. В статье исследуются принципы и способы фактурообразования в музыке для инструментов соло (без сопровождения) в историческом, структурно-функциональном и инструментально-специфическом аспектах. Методология исследования включает использование эстетико-культурологического, исторического, структурно-функиионального музыковедческих методов, которые образуют единую методологическую основу. Научная новизна статьи выражается в выявлении формообразующей, интонационно-мелодической, пространственно-об- 
разной функций фактуры в произведениях для инструмента-соло. Выявляется специфика домровой инструментальной фактуры в указанных функциях. Выводы. В музыке ХХ века наблюдается актуализация сольных инструментальных форм для струнных и духовых инструментов, традииионно звучащих в сопровождении фортепиано, ансамбля или оркестра. За несколько столетий своего существования этот жанр выработал собственные фактурные формы смешанного типа. Их естественно-линеарный принцип развития постепенно вбирал различные виды многоголосной музыкальной ткани (скрытое и явное многоголосие, гомофонно-гармонические элементы, сонористика), что основывается на имманентных интонационных свойствах усложняющейся мелодики, а также создавал собственные, специфические. Перечисленное требует специального исполнительского слышания и способов рельефного выделения в условиях целостного линеарно-вертикально-глубинного пространственного развития сольной инструментальной ткани.

Специфика домрового инструментализма (расположение всех струн в одной плоскости, возможность одновременного использования различных приемов звукоизвлечения, специфические инструментальные приемы) предоставляет значительные возможности дифференцированного исполнения и комбинаторики гомофонно-полифонических фактурных образований. Это позволяет разворачивать сложнуюю драматургию в различных жанрово-стилевых формах сольного домрового инструментализма.

Ключевые слова: соло для струнных музыкальных инструментов, фактура, многоголосие, скрытое многоголосие, гомофония, полифония, домра.

The relevance of the work. Growing from the depths of centuries, receiving a new impetus in the era of the Middle Ages, Renaissance and Enlightenment, and then - in the XX century, solo instrumental culture (unaccompanied) played a huge role both in the development of instrumental play and its expressiveness methods, as well as in the embodiment of epoch-making paradigms of musical thinking in general. Such most important paradigm is the change of polyphonic type of thinking to homophonic and polyphonic, and finally - to homophonic. In the configuration of image and sound, constructive and structural ideas of various eras and styles, the melody becomes a unique phenomenon. According to I. Stravinsky, "modality, tonality, polarity are only transitional means that are outliving or will outlive in the future. The same thing that will be preserved under any modes is a melody" [2, p. 189]. It also becomes the most important structural, image and dramatic element of the texture whole; broadcasts, among other means, "continuous formation", "the merging of discontinuity and continuity"(A. Losev), "continuous melodic fluidity" (B. Asafiev); dictates the development trends of musical form. 
The development of melodic principles coincides in time with the formation of opera-arious creativity and musical and instrumental culture as an autonomous art. The latter reveals the ability to transmit meanings in their "pure" form using, including melodic means "directly", without using verbal meanings [4, p. 445] as "the naked, not covered in anything, unrevealed essence of the world, in-itself-essence, in all its untouched purity and inexpressibility" [1, p. 214]. Having imposed on the tendency of strengthening the individual beginning in the Baroque era, the melody became the main means of expression in music for several centuries, initiating the appearance and development of aria (opera as a whole) and such a specific genre of new musical and instrumental thinking as solo performance, including performance on the instrument of solo without accompaniment. It was in this genre, under the conditions of instrumental utterances individualization from the point of view of personality and the search for new possibilities of the instrument, the melody gained the ability to crystallize its image, structural and logical potentials (of course, such a search went in parallel development and mutual enrichment with arious-opera art).

In the XX century, the positions of the theory of melody and texture are actualized. Accordingly, the genre of instrumental solo receives a new impetus - composer's creativity simply "exploded" with the variety and means of expression of the solo instrumental genre. In particular, these trends affected the plucked folk instrument, domra, which was modernized already at the very end of the XIX century (in fact, for the XX century). Thus, the problems of this article are relevant and modern. The aim of the study is to identify and analyze the specific capabilities of domra texture in music performed without piano or orchestra and ensemble accompaniment.

Presenting the main material. The solo sound of an instrument of a "few-voice nature" (strings, winds) without traditional accompaniment rests, first of all, on the melodic principles of thinking and the developmental process. For the sake of fairness, it is worth noting that the first such experiments (in the New Age, when the instrument itself was improved for such an expression) relate to the practice of lute transcriptions and ensemble or vocal music, dance genres transcriptions of the XV - XVII centuries and are based on the many-voice capabilities of the instrument with simultaneous linear demonstration of linear-melodic and homophonic texture elements. So far, the music itself was in the genre and stylistic field 
of indirect broadcasting, "secondary" of these solo plays in relation to the original compositions in the leading genres of instrumental (ensemble) and vocal music of that era. The plucked lute, rather firmly tied to the function of accompaniment to the vocal, had experience in chord-interval accompaniment formulas, and it was these (with a tendency to nascent homophony) textural skills, along with polyphonic means, that the lute players used in their solo pieces. However, already in the first lute transcriptions, there is an amazing variety of textural forms, "transitional between real and hidden polyphony (as, for example, in Three Fantasies for a lute from the Lviv tablature of the XVI century)" [3, p. 11]. At the same time, in this initial, "transcription" period of the genre's formation, there is a gradual realization of the own musical and expressive possibilities of solo compositions, including specifically instrumental in general and characteristic for these specific instruments. The tools themselves, in turn, are intensively developing at the same time.

So, in the XVI century, the violin displaces the lute - an instrument that is rapidly developing and gaining popularity thanks to the new sound possibilities of articulatory-dynamic and rhythmic plans, which has established itself in the element of folk dance, gradually penetrating the space of church musical culture, containing the necessary potencies for changing epochal musical thinking (homophony). Taking into account the specifics of the instrument, it is, above all, about various forms of hidden and real polyphony. It is no wonder that it was the violin - one of the first to break out at the position of instrumental soloing, also without accompanying homophonic and polyphonic support of other instruments.

The typologization of thematic elements that took place during this period (the concentration of musical imagery in the types of opera arias according to the theory of "affects", in typical dance themes of suites, the formation of an instrumental polyphonic theme) contributed to the formation of the soloism principle with the development of technological and artistic possibilities of the violin as an instrument. Improvement of the instrument itself, the bow, and performing skills paved the way for the active development of the solo-instrumental genre in the compositions of composers of the XVIII - XIX centuries, primarily J. S. Bach and N. Paganini. Compositions by J. S. Bach for violin, cello, flute and other instruments (the era implied their free variation and arrangement) is struck by "the masterful interweaving and mutual 
transitions of the types of hidden voice, their amazing closeness to the forms of real polyphony (italics is ours - I. F.)" [3, p. 11]. The hidden voice in the melodic material of Bach is characterized by an impeccable logic of development and the relief of the elements-layers, which is achieved by relying on the incoming-song horizontal intonation, the homophonic structure of the vertical with the simultaneous manifestation of the principles of unfolding strict style melodies. In such a homophonic and polyphonic context (as in any polyphonic forms), the melodic beginning plays both a shape-forming role and organizes the intonational development of the material. Any melodic material that departs from strict admission contains intonational and constructive prerequisites for polyphony. The latter are formed due to multilevel intonation connections, which determines the integrity of the sounding melody not only in linear-horizontal deployment, but also in two other spatial coordinates - vertical and depth.

Already in the melodic thinking of the closest followers of J. S. Bach-G. F. Telemann, K. F. E. Bach, in parallel with the traditional Bach forms of implicit polyphony, "a different sub-strategy (the term of M. Skrebkova-Filatova - I. F.) is revealed. It refracts the principle of homophonic writing. The degree of intonational and thematic differences between hidden voices increases, which brings the general impression closer to homophonic structures [3, p. 12]. This tendency is even more noticeable in the Caprice of Paganini, where ingenuously virtuoso textured structures are tracing homophonic (quasi-piano) principles of presentation.

The renaissance of solo instrumental sound "from the chill emotion of intellectualism to the expressively pointed intonations of an instrumental monologue - become a kind of symbol, a musical emblem of the ideas of intrapersonal being" of the XX century. And now it's not only bow and flute, but also all string (including modernized plucked ones) and all wind instruments.

The compositions for domra solo, as it were, embody the principle of the old adage "Small spool, but dear". When performer on such a small instrument (with poor, at first glance, textural and dynamic capabilities and repertoire baggage, but unique timbral qualities), they acquire a double meaning. The value of the "small instrument", in our opinion, is in its "new" (for academic music) sound, in solo compositions - it is pure, unaccompanied.

Let us consider these undoubted advantages of an acadamized plucked instrument using the example of "Elegy" for domra solo by 
B. Kravchenko. The composer combined in the texture of the play a beautiful, cantilena melody and plucked accompaniment. The polyphony of the orchestral functions of the melody and accompaniment is enhanced by the timbre-dash contrast of voices.

Elegy begins at the pace of Moderato, for four quarters. An uncomplicated, calm melody is set forth in the second octave with whole notes on a tremolo. The second, accompanying voice sounds in the first octave, is played by taking a guitar pizzicato - only with the fingers of your left hand on the first, third and fourth lobes on another string. Thus, the "orchestral" voices are located in the spaces of different strings, without interfering with each other. In addition, all domra strings have some timbral differences, which also create a spatial differentiation of voices. A note corresponding to the melody is pressed with one finger of the left hand, and a second voice is played with the second finger of the same hand. The right hand plays only tremolo, and it is necessary to carefully ensure that the right hand (with the pick) does not cling to the next string (which can often be found in domra playing), and the quarter accompaniment was performed softly, without jerking and bumps, otherwise the original textured technique will lose its value. Differentiation of voices also occurs due to different loud-dynamic plans, since the right hand forms the volume of the melody and the left "responds" to the accompaniment; they are practically not connected when playing. When playing on a four-string domra, you will have to use a special technique for simultaneously pressing the frets and pinching with your left hand almost constantly. In general, the simultaneous performance of melodies and accompaniment presents considerable difficulty for the domrist even on a three-string.

In the second sentence, the measured, calm presentation of the Theme unexpectedly breaks off in a sixth jump with an arpeggiato chord, immediately after which the tune changes from throttling into third to legato (tremolo with double notes). The balance of the whole is transformed into the turbulent moves of the quarters and eights. The echoes of the accompanying function are now also "dramatized" - in the interval version of the tremolo, it tenses up (compared to the previous simplicity) also the harmony of the echoes - the altered movement is complicated by "freezes" (syncope predictions) in the melody. The texture is compacted, it becomes quasi-orchestral - the number of votes increases, polyphonizes. Thus, the composer embodies the excitement traditional for the middle of the elegiac genre, an emotional upsurge. These four 
measures with the help of textural changes served as a transition to the subsequent development of thematic material. The polyphonic hearing of voices with their autonomous articulations and phrasing in the general procession of music seems very important here. The contrast of the stroke, playing instrumental technique, dynamic plans, and hand coordination require mastery from the performer.

Gradually, the texture loses its density: the upper voice lingers more and more on long notes, accompaniment again switches to monophony, and the dynamics fade. However, for seven measures to the end, but already in a straight form, it comes to a chord on sf (the same jump a sixth up). However, the movement with quarters does not allow reaching the previous tension of climax: there are no double notes with accompaniment, no alterations; a "gap" in the rhythm of accompaniment has appeared. This is just a reflection, a memory of the past. All the more unexpected is the last chord - also sf, with two septims at the bottom. The space is discharged, the domra "demonstrates" its range - from the lower (at the three-string) string $\boldsymbol{e}$ of the first to the cis of the third octave. The effect of calming, completion, fading. These six measures sound in a peculiar inverted form.

The whole composition sounds in one breath and has a through development.

Conclusions. In the music of the XX century, the actualization of solo instrumental forms for strings and wind instruments, traditionally accompanied by a piano, ensemble or orchestra is observed. Over the centuries of its existence, this genre has developed its own textural forms of a mixed type. Their natural-linear principle of development gradually absorbed various types of polyphonic musical texture (hidden and explicit polyphony, homophonic and harmonic elements, sonoristics), which is based on the immanent intonation properties of the complicated melody, and also created its own specific ones. The mentioned above requires special performing hearing and methods of embossing in a holistic linear-vertical-deep spatial development of solo instrumental texture.

The specifics of domra instrumentalism (the location of all strings in one plane, the possibility to simultaneously use different methods of sound extraction, specific instrumental methods) provide significant opportunities for differentiated performance and combinatorics of homophonic and polyphonic textural formations. This allows to deploy complex drama in various genre and style forms of solo domra instrumentalism. 


\section{BIBLIOGRAPHY} 944 c.

1. Лосев А.Ф. Форма. Стиль. Выражение. Москва : Мысль, 1995.

2. Стравинский И.Ф. Хроника. Поэтика. Москва : Центр гуманитарных инициатив, 2012. 368 с.

3. Титова Т.А. Вопросы анализа современной мелодики (на материале произведений для струнных смычковых и духовых инструментов соло) : автореф. дисс. ... кандидата искусствоведения : 17.00.02 ; Российская академия музыки имени Гнесиных. Москва, 1994. 23 с.

4. Chernoivanenko A.D. Musical and instrumental foundations of modern composition techniques. Вісник Національної академії керівних кадрів культури і мистецтв. 2019. Вип. 2. С. 444-448.

\section{REFERENCES}

1. Losev, A.F. (1995). Forma. Stil'. Vyrazhenie [Form. Style. Expression]. Moscow: Mysl' [in Russian].

2. Stravinskiy, I.F. (2012). Khronika. Poetika [Chronicle. Poetics]. Moscow: Tsentr gumanitarnykh initsiativ [in Russian].

3. Titova, T.A. (1994). Voprosy analiza sovremennoy melodiki (na materiale proizvedeniy dlya strunnykh smychkovykh i dukhovykh instrumentov solo) [Questions of the analysis of modern melody (based on works for stringed bowed and wind instruments solo)]. Candidate's thesis. Moscow: Gnessin Russian Academy of Music [in Russian].

4. Chernoivanenko, A.D. (2019). Musical and instrumental foundations of modern composition techniques. Visnyk Natsionalnoi akademii kerivnykh kadriv kultury i mystetstv - National Academy of Managerial Staff of Culture and Arts Herald, issue 2, pp. 444-448 [in English]. 